\title{
The Impact of Regional Integration on Intra-Arab Trade in Agrifood Commodities: A Panel Data Approach

\author{
Assem Abu Hatab*
}

Suez Canal University, Al-Arish, Egypt

Heliopolis University for Sustainable Development, Egypt

Abstract

This paper assesses the impact of regional integration arrangements on intraArab agrifood trade. The main results indicate that Arab regional integration efforts have been ineffective in promoting agrifood trade flows among the Arab countries. The results also show that actual intra-Arab agrifood trade is consistently lower than the predicted values by the gravity model. Furthermore, Arab sub-regional trade agreements have had a modest impact on intra-Arab agrifood trade. Taken together, these findings suggest that i) there is untapped trade potential in agricultural and food commodities among the Arab counties and thus they could potentially attain deeper levels of agrifood trade integration, and ii) despite the significant progress that has been made over the past two decades in lowering tariff barriers, agrifood trade among Arab countries has remained below its potential which in turn points out to the existence of non-tariff barriers that restrain the trade effects of Arab economic integration.

Jel Classification : C1, F02, F15, F53

Keywords : Regional trade integration, intra-Arab trade, agrifood trade, panel data.

Acknowledgement : The author gratefully acknowledges financial support from the Arab Fund for Economic and Social Development.

\section{Introduction}

The Arab region faces severe food security challenges underpinned, among others, by strong population growth, low agricultural productivity and dependency on global commodity markets (IFPRI Middle East and North Africa Strategy). According to IFAD and FAO, Arab countries are outstandingly vulnerable to fluctuations in global food prices while most of them import at least $50 \%$ of their consumption of food calories. Over the next 20 years, projections of food balance in the region indicate that dependence on imports will increase by almost $64 \%$ (IFAD and FAO). Moreover, the Arab region is the most water scarce region in the world and it is projected to be deeply impacted by the consequences of climate change (Assem; Cline). Furthermore, regional and inter-state conflicts within the region continue to disrupt development and economic growth and to raise further concerns about food security.

In recognition to these common challenges that increasingly threaten the future of food security in the region, several attempts aiming at achieving closer cooperation and economic integration among Arab countries have been made since the second half of the past century. Neaime points out that the history of trade integration in the Arab world dates back to 1945 when the Arab League was created while the founding

\footnotetext{
* Assem Abu Hatab, Department of Economics, Suez Canal University, Al-Arish 44615, North Sinai, Egypt, Tel: +2(0)68-3320 385, Fax: +2(0)68-3320 384, assem.abouhatab@gmail.com
} 
document articulated a number of legislative texts and institutional structures with a strong commitment to promote economic cooperation and intra-Arab trade (Abu Hatab). In 1953, the Economic and Social Council of the Arab League approved the first agreement on Trade Facilitation and Organizing Transit Trade among Arab States(Terad). In 1957, a project with the aim to free the circulation of people and capital, and the establishment of a common customs area was approved under the title "the constitution of Economic Union among the Arab States". This agreement came to effect with a decision in 1964 for the creation of a common market among seven Arab states(Babili and Baghasa). The main principles of this agreement included successive reductions in tariffs and taxes and the elimination of administrative barriers until the achievement of a full-trade liberalization among the joining countries(Romagnoli and Mengoni "The Challenge of Economic Integration in the Mena Region: From Gafta and Eu-Mfta to Small Scale Arab Unions").

With the emergency of powerful trading blocs in the post-cold war era, a global tendency was seen in both the developed and developing world toward the creation of trade blocs as means to promote economic growth(Baldwin). In turn, during the 1980s and the 1990s, regional integration became even a more attractive policy option for Arab countries. In 1981, Arab countries signed an agreement for the "Facilitation and Promotion of Trade among Arab States" which aimed to extend the Arab Common Market agreement to all member countries of the Arab League. With respect to agriculture, this agreement fully exonerated agricultural products originated in the countries signing the agreement both in their raw and manufactured forms from import tariffs and taxes(Malvarosa). During the Arab Summit in Cairo in 1996, a program for the creation of the Greater Arab FreeTrade Area (GAFTA) was adopted and then came into force in January 1998 in order to set up a free-trade area among eighteen Arab countries. Beside these region-wide agreements, Arab integration efforts extended to include the creation of sub-regional economic unions(Hakimian and Nugent). Examples of these sub-regional economic agreements included the creation of the Gulf Cooperation Council (GCC) in 1981, the Arab Maghreb Union in 1989 (AMU), the Arab Cooperation Council in 1989 and the Agadir Agreement in 2007 (Romagnoli and Mengoni The Economic Development Process in Mena).

Notwithstanding the several steps that Arab counties have taken to promoting trade relations and economic integration, the Arab region has -in comparison to other regions of the world- the lowest levels of regional integration (Harrigan The Political Economy of Arab Food Sovereignty). Despite the relative homogeneity in terms of religion, culture and language along with the preferential market access, the effectiveness of regional integration in the Arab world is an empirical issue. During the period 1994-2013, IAAT averaged merely $18.2 \%$ of total Arab agrifood trade with the world. Although a comprehensive evaluation of the unsuccessful implementation of Arab regional trade agreements is beyond the scope of this paper, several studies have attributed this failure to both economic and institutional factors. The major economic ones include differences in individual Arab economic systems, the similarity of production and trade structures, the overprotection and heavy 
reliance on trade taxes, the lack of convertibility of Arab currencies, the low quality and thus low competition of Arab commodities against imported products from other regions of the world and the lack of market information and adequate infrastructure. Meanwhile, the institutional factors include the high sensitivity of trade to political relationships among Arab countries, the lack of commitment to the regional agreements, the absence of adequate trade financing schemes at the regional level, and the bureaucracy and complications of trade-related procedures, among others (Limam and Abdalla; Abu Hatab; Bolbol; Bolbol and Fatheldin; Zarrouk "A Survey of Barriers to Trade and Investment in Arab Countries").

A close investigation of the economic literature on IAAT shows that there are a voluminous number of studies that have analyzed Arab integration. However, the existing literature suffers from two important and related defects. First, it remains dominated by descriptive analyses and lacks a solid empirical evidence on the determinants and impacts of regional integration on intra-Arab trade flows(Abu Hatab; Bayar; Limam and Abdalla; Zarrouk "The Greater Arab Free Trade Area: Limits and Possibilities"; Zarrouk "A Survey of Barriers to Trade and Investment in Arab Countries"; Galal and Hoekman). Second, the bulk of the few empirical studies that investigated the effects of regional economic integration on trade among the Arab countries are carried out using a highly aggregated level of data (overall trade); whilst sector-level analyses, especially on agriculture and food sectors, at disaggregated data levels have not been investigated rigorously (Abedini and Péridy; Neaime; Taleb and Younes; Younes).

The present paper attempts to overcome the limitations of the literature by applying a panel data approach to sector-level data, namely, food and agricultural commodities, to empirically analyze the IAAT and measure the impacts of regional trade integration on agrifood trade among the Arab countries. It therefore contributes to the literature in two aspects. It adds to the existing empirical literature on the determinants and impacts of Arab economic integration. Second, it focuses on agrifood sector which received less attention in the existing literature despite the increasing food security concerns facing the region. Moreover, the policy implications drawn from this paper would be useful to Arab policymakers and trade stockholders to revisit existing integration efforts and formulate strategies to help achieving the full potential and beneficial effects of trade liberalization and economic integration. The organization of this paper can be briefly outlined as follows. The following section enumerates the performance of IAAT in the past two decades. Section 3 presents the econometric model. Section 4 presents the results and Section 4 concludes by highlighting some policy recommendations to boost agricultural trade among Arab countries.

\section{Overview Of Intra-Arab Trade In Agri-Food Commodities}

A plenty of studies have shown that regional integration enhances bilateral trade, economic development and growth in the integrated countries (Dennis; Lloyd and MacLaren; Wacziarg; Wilson, Mann and Otsuki; Younes). In this context, the literature suggests thatregional integration can potentially affect trade and economic growth through a number of channels, including; increasing competition and raising 
production efficiently due to allocation impacts resulting from lowering intra-regional tariffs, capturing the benefits of the increasing returns to scale due to the enlargement of the size of the market, and enhancing knowledge transmission and technological innovations among the integrated countries (Alcalá and Ciccone; Barro and Sala-iMartin; Dobrin; Wilson, Mann and Otsuki).

Recognizing these positive spillover effects of regional integration, the relevance of regional integration in the Arab region becomes a persistent issue, specifically in view of the increasing agriculture and food security challenges in the Arab region. Figure 1 depicts the development in IAAT during the period 1994-2013. Between 1997 and 2008, agrifood trade among the Arab countries increased dramatically from USD 2.2 billion to about USD 21.8 billion in 2008, a tenfold increase over a decade with an average growth rate of about 13 percent. In particular, the early years of this period witnessed the creation of a web of agreements among countries of the region, for instance: Egypt, Jordan, Tunisia and to somewhat Morocco signed series of bilateral and regional agreements with other Arab states during this period, the Gulf Cooperation Council (GCC) declared a custom union among its member states in 2003, and the Agadir agreement entered into force in 2004.

Figure 1: Development in intra-Arab Agri-food Trade, 1994-2013

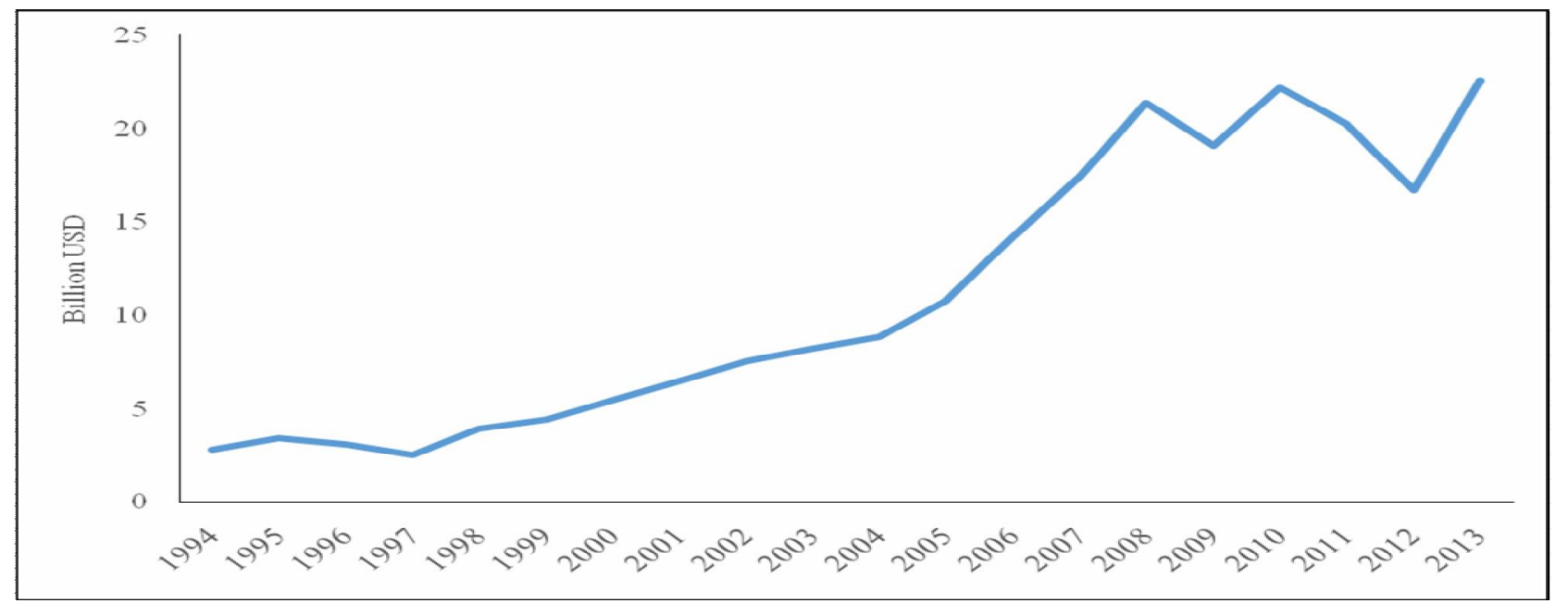

Source: World Bank, WITS, 2015

Since 2008, the performance of IAAT has been characterized by slight fluctuations averaging USD 20.2 billion between 2009 and 2013, and ranging between USD 16.7 billion in 2012 and USD 22.6 billion in 2013. These declines can be mainly attributed to the food crisis in 2008-2009 which negatively affected the level of demand for agri-food commodities in Arab countries. Moreover, intra-Arab trade suffered since 2011 from socio-political disturbances in several Arab countries including Egypt, Syria, Libya and Yemen, which are large exporters and importers of agri-food commodities, leading to disruptions in economic activity and impacts on the volume of IAAT.

In relative terms, Figure 2 points out that the share of IAAT in total intra-Arab trade has increased from $21 \%$ in 1994 to about $25.1 \%$ in 1999 . However, the contribution of agri-food IAT to the overall IAT has generally taken a downward trend since 2001 and characterized by sharp fluctuations, ranging between $14.3 \%$ in 
2005 and $23.5 \%$ in 2001 and averaging $19.6 \%$ of the overall IAT during the period 1994-2013. With this average share in IAT, agri-food commodities represent the third main traded products among Arab countries, after fuel and manufactured products(Abedini and Péridy).

As a proportion of total Arab trade in agri-food communities with the world, Figure 2 shows that the share of IAAT ranged between about 13\% in 1997 and $23.8 \%$ in 2006, averaging about $18.2 \%$ of total Arab agri-food exports and imports during the period 1994-2013.

Figure 2: Relative importance of Agri-food IAT in Arab trade, 1994-2013

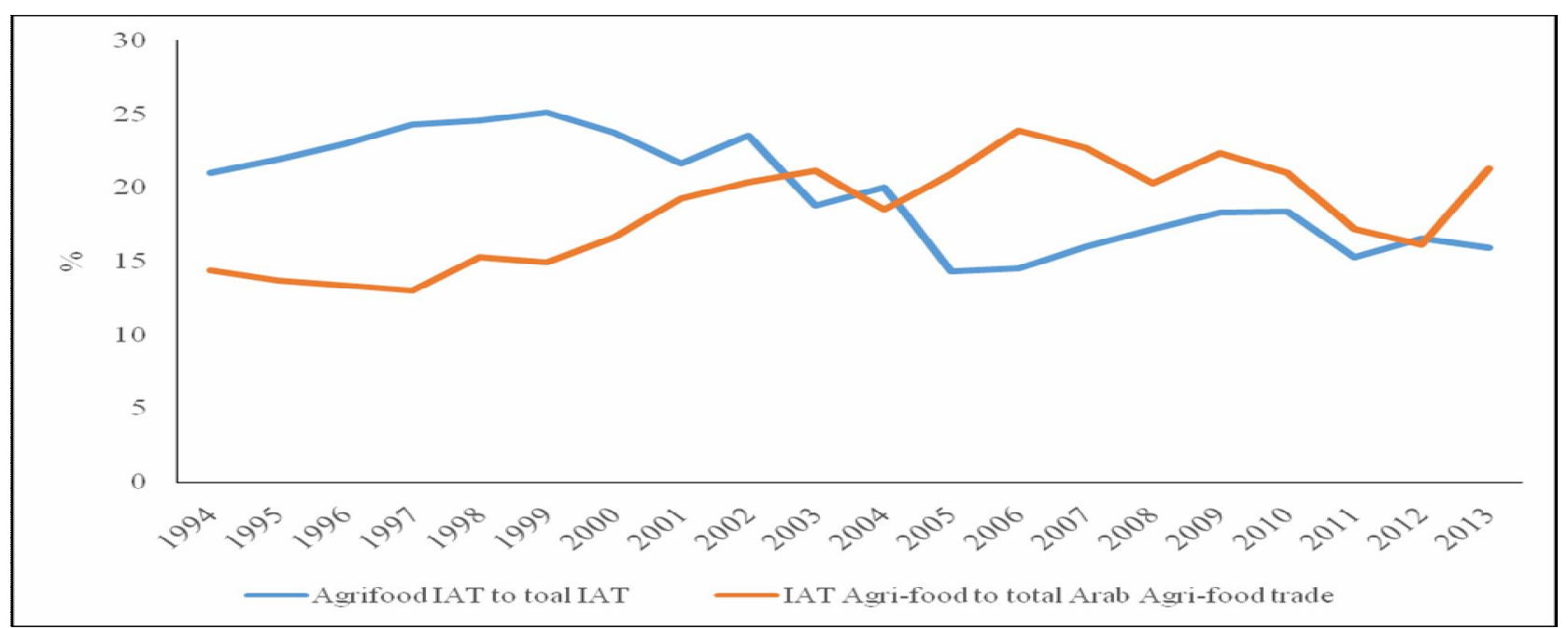

Source: world Bank, WITS, 2015

Figure 3 illustrates the categorical composition of IAAT during the period 1994-2013 while points out to the high product concentration of agri-food trade among Arab countries. Most notably, vegetables and fruit represented slightly more than one-quarter of the overall IAAT. The sub-categories of " Dairy products and

Figure 3 Composition of agri-food IAT, 1994-2013

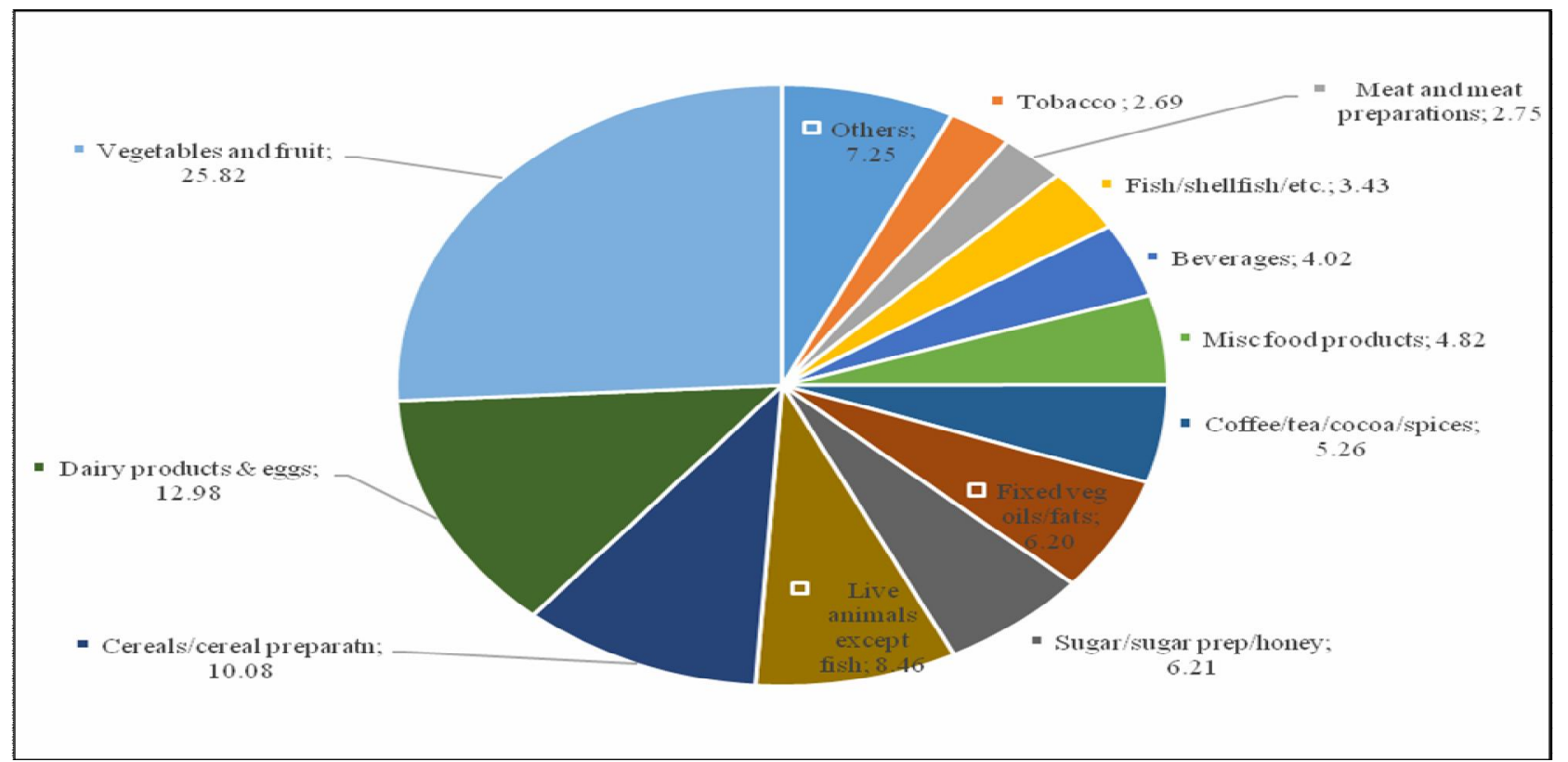

Source: world Bank, WITS, 2015 
eggs" and "Cereals and cereal preparations" follow with proportions of about $13 \%$ and $10.1 \%$, respectively. Trade within these three sub-categories calculated for about half of IAAT, whilst the share of other sub-categories. Conversely, the shares of other sub-categories appear relatively less important for IAAT.

In sum, one could conclude some characteristics of IAAT which can be summarized as follows: i) the volume of IAAT has been steadily increasing over time but trade has suffered from fluctuations and instability in recent years, ii) in contrary, the share of IAAT has generally continued to decline during the period understudy, iii) IAAT is concentrated in a few number of commodity group, namely; horticultural commodities, dairy products and eggs, and cereals.

\section{METHODOLOGY}

\section{A. Model Specification}

To achieve the objective of this paper, an econometric model based on a gravity model equation was utilized to examine the determinants of IAAT. Since its first application to international trade during the sixtieth by Tinbergen and Poyhonen, the gravity model has proved to be one of the most powerful methods to explain bilateral trade flows among countries. The model is based on Newton's law of universal gravitation with the basic idea that trade flows among countries is proportional to the product of their sizes, measured by their respective GDPs, and inversely proportional to the distance between them. Other explanatory variables that are typically included in gravity models are population or per capita GDP and dummy variables reflecting contiguity; geographical and cultural proximity such as common boarders and common language, and also participation in various regional trading arrangements.

Gravity models gained popularity due to their concept simplicity, appropriateness to fit well the available data, and the relative straightforwardness of their econometric estimation(Abu Hatab, Romstad and Huo; Trabelsi; Westerlund and Wilhelmsson). A close look at the recent literature on international trade reveals that many authors have employed gravity models to empirically investigate several trade related issues including the determinates of trade and the calculation of trade potentials(Egger "An Econometric View on the Estimation of Gravity Models and the Calculation of Trade Potentials"; Rojid), impact of regional and multinational trade agreements(Martínez-Zarzoso, Felicitas and Horsewood; Sarker and Jayasinghe), impacts of currency unions (De Sousa; Tenreyro)), determinants and impacts of foreign direct investments(Bénassy Quéré, Coupet and Mayer; Bevan and Estrin)and the impacts of tariffs and non-tariff barriers of trade(Beghin and Bureau; Ferrantino).

The econometric panel data gravity model used in this econometric exercise can be written as follows:

$m M_{i j t}=\beta_{0}+\beta_{1} m G D P_{i t}+\beta_{2} m G D P_{j t}+\beta_{3} \ln G D P C A P_{i t}+\beta_{4} \ln G D P C A P_{i t}+\beta_{3} \ln D S T_{i t}+\sum_{1}^{n} \chi_{i} R E G I D N_{i j}+\sum_{i}^{2} \delta_{i} A R A B_{i j}+s_{i j t}$

Where $\beta 0$ is the constant, $\mathrm{M}_{\mathrm{ijj}}$ represents the value of agrifood imports of reporting country $i$ from export partner $j$ at year $t$ during the period 1995-2013. GDP $P_{i t}$ and $G D P_{j t}$ represent the real gross domestic product of the report and import market. 
Likewise, GDPCAP $i \varepsilon$ and $\beta_{4} G D P C A P_{j t}$ is the real per capita GDP of the reporting and partner county. Moreover, a number of a country and time invariant set of variables that may favor or limit bilateral trade were included in the econometric model including the geographical proximity measured by the physical distance between importer's and exporter's capital city ( $\left.D I S T_{i c}\right)$. Moreover, we introduced a number of dummy variables under $R E G I O N_{i j}$ to capture the impact of different regional trade agreements on the volume of trade flows among the included countries. These agreements consist of the ASEAN, EU, COMESA along with three major Arab regional agreements, namely; the Gulf Cooperation Council (GCC), the Arab Maghreb Union (AMU) and the Agadir Agreement (AA). Finally, following Al-trash and Yousef and Yihong and Weiwei, two dummy variables in $A R A B_{i j}$ including $\left(A_{r a b} b_{R o W}\right)$ were introduced to measure agrifood trade integration between Arab countries and the rest of the world, and $\left(A r a b_{A R}\right.$. $)$ which captures agrifood trade integration among countries of the Arab region. The variable $\left(\operatorname{Arab}_{R o W}\right)$ takes value unity if the reporting country is an Arab country, whereas the dummy variable $\left(\right.$ Arab $\left._{A R .}\right)$ takes value unity if the importer and partner both are Arab countries.

\section{B. Data and data sources}

This econometric analysis in this paper focuses mainly on agrifood trade among an eighteen Arab countries during the period 1995-2013. The dataset involve the 18 Arab countries and their 46 maintrading partners including the EU 28 members, the US, Canada, Australia, Russia, and 14 Asian and African non-Arab countries. These countries collectively supplied the Arab world with roughly $92 \%$ of its total agricultural and food imports during the period understudy.

Annual data on agrifood trade, accounted for in CIF prices for imports and FOB prices for exports in thousands US dollars, were compiled from the World Bank-World Integrated Trade Solutions database (WITS). The composition of agricultural and food commodities was based on the Standard International Trade Classification (SITC) Revision 3 of COMTRADE that considers the sum of commodity groups/subgroups 0 (food and live animals), 1 (beverages and tobacco), 22 (oil seeds/ oil fruits), 23 (crude/ synthetic/ rubber), 24 (cork and wood), 25 (pulp and waste paper), 26 (textile fibers), 29 (crude animal/vegetable materials res) and 4 (animal oil/fruit/ wax) as total agrifood trade flows.GDP related data were collected from the World Bank-World Development Indicators. Data on geographic proximity (distance) were extracted from the database of the French Research Center in International Economics (CEPII). Information on countries' membership in regional trade agreements was gathered from the official websites of these agreements and the respective authorities in different countries.

Even though the present study focuses on agricultural and food commodities and thus estimation results won't be influenced by the bias resulting from oil exports, the imports volume $\left(\mathrm{M}_{\mathrm{ijt}}\right)$ was used as dependent variable in order to mesh with the exiting literature pointing out that imports equation is more likely to provide insight understanding of intra-Arab trade and thus we focused on imports in order to be able to compare the results of this analysis with previous studies findings(Al-Atrash and Yousef; Kleiman). 


\section{9 r 1 The Impact of Regional Integration on Intra-Arab Trade in Agrifood Commodities: A Panel Data Approach \\ C. Estimation Procedures \& Expected Results}

In this dataset, there were a number of Zero-trade values and missing observations which calculate for approximately $18 \%$ of the total observations. To cope with this problem, the study followed Head et al. (2010) that suggest dropping country pairs with Zero trade and missing observations. To correct for the possible endogenity of trade, the model was estimated using two-stage least squares methodology (2SLS) with instruments. Previous studies indicate that this methodology requires a good instrumental variable which can satisfy two conditions, namely; to be exogenous yet highly correlated with trade(Egger $O n$ the Problem of Endogenous Unobserved Effects in the Estimation of Gravity Models; Eichengreen, Rhee and Tong; Redding and Venables). In this context, a variable such as "distance" represents a good instrumental variable given that it is plausibly exogenous and in the same time is highly correlated with trade. Moreover, a number of previous studies point out that the GDPs of trading partners is exogenous as well(Frankel and Rose; Greenaway, Mahabir and Milner). Based on that, the estimation of the gravity model followed an intuitive two-stepimplementation of this idea. In the first regression stage, the potentially endogenous variable is used as the dependent variable, whereas all the exogenous variables from the model are included as independent variables. In the second stage of the estimation, the estimated values of the dependent variable from the first stage regression are used in place of the problematic variable in the gravity model itself(Shepherd).

While the 2SLS technique is efficient only when errors are homoskedastic, a Pagan and Hall test of heteroskedasticity for instrumental variables (IV) estimation was run(Greenaway, Mahabir and Milner). We did not correct for heteroskedasticity because the Pagan and Hall test could not reject the hypothesis of the homoscedasticity of the residuals. This therefore confirms that the 2SLS estimation technique is an appropriate approach for the estimation of the gravity model equation. The sings on the estimated coefficients are expected to be as follow; the economic size, measured by GDP of reporting and partner countries, is expected to positively influence trade flows among countries. The coefficient estimate for per capita income of the importing country could be either positive or negative(Kavallari, Maas and Schmitz). According to the Heckscher-Ohlin hypothesis, countries with dissimilar levels of per capita income will trade more than countries with similar levels. Contrarily, the Linder hypothesis says that bilateral trade increases when countries have similar per capita income(Martínez-Zarzoso and Nowak-Lehmann).

The distance variable, as a proxy for transportation costs, is expected to act as a trade barrier and thus negative sign is expected. The more distant to pair countries, the higher transportation costs, the lower the trade flows. With regard to the included dummy variables, countries that belong to the same trade agreement are theoretically predicted to trade more. In relation to the variable of our interest $\left(A r a b_{A R}\right)$, the expected sign could be positive or negative. More specifically, a positive sign means that trade flows would increase with the pair of countries being Arab States, whilst a negative sign would indicate an inverse correlation between the total volume of imports and exporter and importer being both Arab countries. 


\section{Results and Discussion}

Table 2 summarizes the results of the gravity model equation (1) for import flows among the countries understudy. R-squared values range from 0.511 to 0.595 which suggests that the model fits the data well. By and large, gravity type control variables in the three estimated models (aggregated estimation, disaggregated estimation based on import data and disaggregated estimation based on total trade) have the expected sign and their magnitude go in line with the theory of gravity. The GDP of both importer and exporter have a significantly positive effect on trade flows. Moreover, trade rises with the increase in the GDP per capita of the importing and supplying countries. Transportation cost, proxied by the distance variable has a highly significant negative effect on trade flows. Given the perishable nature of agrifood commodities, trade falls when the physical distance between countries increase. Enhancing the business environment by investing in both transportation and communication infrastructure to reduce transaction cost could improve the overall competitiveness of Arab countries and boost intra-agrifood trade.

A look at the results of the aggregated model (column1 in Table 2) shows that the dummy variable $(\operatorname{Arab} A R)$ has a negative and a statistically significant coefficient of (-0.528). This indicates that controlling for other factors, agrifood trade significantly declines with the pair of trading partners being Arab countries. This finding suggests that agrifood trade flows among the Arab countries are consistently lower than predicted by the model. It also implies that there exist factors that weaken the trade effects of Arab economic integration and free trade agreements. These results go in line with the findings of previous studies which indicate that Arab region has lower levels of intra-regional trade in comparison to other regions of the world and that trade potential exists but is as yet unexploited(ITC; Abdmoulah).

With regard to Arab agrifood trade with the rest of the world, the results show that, other things being equal, Arab countries tend to trade more with the rest of the non-Arab countries of the world. Specifically, the high significance of the dummy variable (ArabRoW)confirms the heavy reliance of Arab countries on the global agrifood markets. This finding coincides also with previous studies that have shown that Arab countries rely on a trade-based approach to food security - that is, to depend heavily on importedfood(Harrigan Food Security in the Middle East and North Africa (Mena) and Sub-Saharan Africa: A Comparative Analysis; IFPRI Food Security and Economic Development in the Middle East and North Africa: Current State and Future Perspectives).

Under resource endowments constraints, particularly severe water and arable land scarcity, many countries in the region find it economically rational to allocate their resources to produce other goods for export and use the foreign exchange earned to purchase imports for much of their food requirements (Harrigan The Political Economy of Arab Food Sovereignty). However, this leaves Arab countries vulnerable to fluctuations in international commodity markets food price shocks and it also could lead to significant negative food security impacts (Lampietti et al.)

Moreover, the results reveal that the impact of regional trade agreements on intra-Arab agrifood trade is modest. Particularly, the results show that GCC agreement has a negative but statistically insignificant impact on agrifood trade 
among member states. This is partially due to the lack of economic diversification and the heavy reliance of the Gulf countries oil and gas exports which represent more than 80 percent of their exports and also the similar production structures which limit intra-GCC trade. Likewise, the Arab Maghreb Union hasnot promoted greater trade integration among the member countries. Contrarily but under lower level of statistical confidence, Agadir agreement has a positive significant trade creation effect within its members in agrifood trade.

Table 1: Estimation Results of the gravity model (Dependent variable is log of agrifood imports)

\begin{tabular}{|c|c|c|c|}
\hline \multirow[b]{2}{*}{ Variables } & \multirow{2}{*}{$\begin{array}{c}\text { Aggregated model } \\
\text { (1) }\end{array}$} & \multicolumn{2}{|c|}{ Disaggregated model } \\
\hline & & $\begin{array}{l}\text { Imports } \\
(2)\end{array}$ & $\begin{array}{l}\text { Total Trade } \\
\text { (3) }\end{array}$ \\
\hline \multirow{2}{*}{ Reporter GDP } & 0.545 & 0.681 & 0.7340 \\
\hline & $(0.025)^{* * *}$ & $(0.288)^{* * 4}$ & $(0.011)^{*}$ \\
\hline \multirow{2}{*}{ Partner GDP } & 1.160 & 1.343 & 1.396 \\
\hline & $(0.122)$ & $(0.008)$ & $(0.008)$ \\
\hline \multirow{2}{*}{ Reporter GDP Per Capita } & $0.322^{*}$ & $0.313^{*}$ & $0.417^{* 14}$ \\
\hline & $(0.0270)$ & $(0.167)$ & $(0.204)$ \\
\hline \multirow{2}{*}{ Partner GDP Per Capita } & $0.257^{* * *}$ & $0.288^{*}$ & 0.321 \\
\hline & $(0.010)$ & $(0.133)$ & $(0.193)$ \\
\hline \multirow{2}{*}{ Distance } & $-1.463^{* * *}$ & $-2.870^{* * * *}$ & $-3.106^{* * *}$ \\
\hline & $(0.138)$ & $(0.385)$ & $(0.922)$ \\
\hline \multirow{2}{*}{$A S E A N$} & $0.513^{* * * *}$ & $0.738^{* * * * *}$ & $0.838^{* * * *}$ \\
\hline & $(0.087)$ & $(0.011)$ & $(0.073)$ \\
\hline \multirow{2}{*}{$\boldsymbol{E} \boldsymbol{U}$} & $0.369^{* *}$ & $0.423^{* * *}$ & $0.507^{* * *}$ \\
\hline & $(0.172)_{*}$ & $(0.064)$ & $(0.045)$ \\
\hline \multirow{2}{*}{ COMESA } & $0.323^{* * *}$ & $0.378^{* * * *}$ & $0.387^{* * 4}$ \\
\hline & $(0.117)$ & $(0.129)$ & $(0.154)$ \\
\hline \multirow{2}{*}{$G C C$} & -0.116 & -0.122 & $-0.021^{*}$ \\
\hline & $(0.202)$ & $(0.203)$ & $(0.011)$ \\
\hline \multirow{2}{*}{$\boldsymbol{A} \boldsymbol{A}$} & $0.298^{* * 4}$ & $0.480^{*-4}$ & $0.498^{* * 4}$ \\
\hline & $(0.131)$ & $(0.210)$ & $(0.203)$ \\
\hline \multirow{2}{*}{$\boldsymbol{A M U}$} & 0.113 & 0.287 & 0.238 \\
\hline & $(0.366)$ & $(0.247)$ & $(0.121)$ \\
\hline \multirow{2}{*}{$\operatorname{Arab} A R$} & $-0.528 * *$ & ----- & ----- \\
\hline & $(0.042)$ & ------ & ------ \\
\hline \multirow{2}{*}{ ArabRoW } & $1.306^{* * * *}$ & ------ & ----- \\
\hline & $(0.020)$ & ------ & ------ \\
\hline \multirow{2}{*}{ Arabian Peninsula } & ------ & 0.168 & 0.239 \\
\hline & ------ & $(0.192)$ & $(0.123)$ \\
\hline \multirow{2}{*}{ Levant } & ------ & 0.378 & 0.631 \\
\hline & ------ & $(0.154)$ & $(0.313)$ \\
\hline \multirow{2}{*}{ Maghreb } & ------ & $0.240^{*}$ & $0.325^{*}$ \\
\hline & ------ & $(0.126)$ & $(0.197)$ \\
\hline $\mathbf{R}^{2}$ & 0.5946 & 0.5106 & 0.5731 \\
\hline F-test & $350.987[0.000]$ & $94.221[0.000]$ & $65.740[0.000]$ \\
\hline Endogenity test & $302.353[0.000]$ & $107.894[0.000]$ & $316.543[0.000]$ \\
\hline Hansen J-statistics & $214.221[0.000]$ & $152.216[0.000]$ & $139.321[0.000]$ \\
\hline Obs. & 4500 & 4500 & 4500 \\
\hline
\end{tabular}

Note: *Significant at 10\%; ** Significant at 5\%; and *** Significant at 1\%. All other variables are statistically insignificant.

Column 2 and Column 3 in Table 2 summarizes the estimation results of the gravity equation under the disaggregation of the Arab world into three sub-regions (Arabian Peninsula countries, Levant Countries and Maghreb Countries) while the dependent variable is agrifood imports in Column 2 and total agrifood trade in in 
Column 3. The categorization of Arab counties into these three sub-regions was based on the classification of Dabour and Dabour. A critical look at these results reveals that the values, signs and significance of the coefficients are not too different from the results of the aggregated model. More importantly, the results of the disaggregated models suggest that the Arabian Peninsula countries tend to trade less among themselves. At the $10 \%$ significance level, results illustrate that trade arrangements among the Maghreb countries yield a positive effect on intra-group agrifood trade. In comparison to other sub-regions, the results imply that the Levant countries havedone a relatively better job in achieving deeper levels of agrifood trade integration.

\section{Summary and Concluding Remarks}

The paper aimed to assess the impact of regional trade integration among Arab countries on their intra-agrifood trade. To this end, the paper employed a gravity model approach to a panel dataset covering agrifood trade of 18 Arab countries and their 46 main trading partners during the period 1995-2013. The results indicate that the gravity equation fits the data and delivers plausible estimates for the explanatory variables and in line with the theory.

The econometric results show that agrifood trade flows among the Arab countries are consistently lower than they could be. Moreover, the results by and large indicate that Arab regional trade agreements have had a modest impact on intraArab agrifood trade and have been ineffective in promoting greater trade integration among the Arab countries. These two findings suggest that the following; first, there exists untapped trade potential among the Arab counties Arab countries and they could potentially attain deeper levels of agrifood trade integration. Second, it is quite obvious that there exist uncertain impediments that restrain the trade effects of Arab economic integration.

Based on these findings, the policy recommendation that can be drawn is that Arab counties need to endorse a multi-layered approach to different barriers hindering the movement of agrifood commodities among the countries of the region. It is worth stressing in this regard that efforts should be focused on the elimination of non-tariff barriers. This is because despite the significant tariff reductions within the framework of Arab regional trade agreements, agrifood trade among Arab countries has remained below its potential which in turn points out to the existence of non-tariff barriers (such as, lack of uniform standards and harmonization, quality and health standards, import levies and quantitative restrictions along with pervasive bureaucracy and red tape) that block intra-agrifood trade flows among the Arab countries. In the same context, the estimated results illustrate that partially due to the perishable nature of many agrifood commodities; physical distance between Arab countries has a statistically high significant negative impact on intra-Arab agrifood trade. The policy implication from this finding is that Arab countries need to invest heavily in trade-related infrastructure and trade facilitation to upgrade the infrastructure linkages and promote intra-agrifood trade. Reducing transaction costs could be also achieved by improving the efficiency of the inspection and customs services in Arab countries to facilitate the trade flows of fresh produce that often 
must arrive quickly on store shelves. Moreover, the adoption of modern technologies helps overcome the distance barrier as modern communication systems allow better monitoring of quality, tracking and coordinating different steps through the marketing chain of time-sensitive agrifood commodities. However, pushing forward the implementation of such reforms requires a strong political will and close coordination between respective authorities and the private sector in Arab countries.

\section{References}

- Abdmoulah, Walid. "Arab Trade Integration: Evidence from Zero-Inflated Negative Binomial Model." Journal of Economic Cooperation and Development 32.2 (2011): 39-66. Print.

- Abedini, Javad, and Nicolas Péridy. "The Greater Arab Free Trade Area (Gafta): An Estimation of Its Trade Effects." Journal of Economic Integration 23.4 (2008): 84872. Print.

- Abu Hatab, Assem. "Opportunities and Challenges for Intra-Arab Trade: The Role of Arab League Specialized Organizations and Federations." Conference on Towards a Strategy to improving the role of Arab League Specialized Organizations and Federations in promoting Pan-Arab Economic Cooperation. Arab Federation for Wildlife Protection, Council for Arab Economic Unity, the Arab League, 2015. Print.

- Abu Hatab, Assem , Eirik Romstad, and Xuexi Huo. "Determinants of Egyptian Agricultural Exports: A Gravity Model Approach." Modern Economy 1.03 (2010): 134. Print.

- Al-Atrash, Hassan, and Tarik Yousef. Why Intra-Arab Trade: Is It Too Little?2000. Print.

- Alcalá, Francisco, and Antonio Ciccone. "Trade, Extent of the Market and Economic Growth 1960-1996." (2003). Print.

- Assem, Abu Hatab. "Water Scarcity and Water Trade: An Analysis of the Determinants of Virtual Water Flows to the Gcc Countries." Qatar Foundation Annual Research Conference Proceedings (2014): SSPP0126. Print.

- Babili, Mahmoud, and Hajar Baghasa. The Impacts of Gafta on Syrian Trade after Its Full Implementation2008. Print.

- Baldwin, Richard E. "Review of Theoretical Developments on Regional Integration." Regional integration and trade liberalization in sub-Saharan Africa 1 (1997): 24-88. Print.

- Barro, Robert J, and Xavier Sala-i-Martin. "Technological Diffusion, Convergence, and Growth." Journal of Economic Growth 2.1 (1997): 1-26. Print.

- Bayar, Ali. "An Evaluation of the Benefits and the Challenges of the South-South Integration among the Mediterranean Partner Countries." FEMISE Research Network, 2004. Print.

- Beghin, John C, and Jean-Christophe Bureau. "Quantitative Policy Analysis of Sanitary, Phytosanitary and Technical Barriers to Trade." Économie internationale 87.3 (2001): 107-30. Print. 
- Bénassy Quéré, Agnès, Maylis Coupet, and Thierry Mayer. "Institutional Determinants of Foreign Direct Investment." The World Economy 30.5 (2007): 76482. Print.

- Bevan, Alan A, and Saul Estrin. "The Determinants of Foreign Direct Investment into European Transition Economies." Journal of comparative economics 32.4 (2004): 775-87. Print.

- Bolbol, Ali A. "Arab Trade and Free Trade: A Preliminary Analysis." International Journal of Middle East Studies 31.01 (1999): 3-17. Print.

- Bolbol, Ali A, and Ayten M Fatheldin. "Foreign and Intra-Arab Capital Flows in the Arab Countries, 1990-2003." The World Economy 29.9 (2006): 1267-93. Print

- Cline, William R. "Global Warming and Agriculture: Impact Estimates by Country (Washington: Center for Global Development and Peterson Institute for International Economics)." (2007). Print.

- Dabour, Nabil. "Water Resources and Their Use in Agriculture in Arab Countries." Journal of Economic Cooperation 27.1 (2006): 1-38. Print.

- Dabour, Nabil Md. "The Role of Irrigation in Food Production and Agricultural Development in the near East Region." Journal of Economic Cooperation 23.3 (2002): 31-70. Print.

- De Sousa, Jose. "The Currency Union Effect on Trade Is Decreasing over Time." Economics Letters 117.3 (2012): 917-20. Print.

- Dennis, Allen. "The Impact of Regional Trade Agreements and Trade Facilitation in the Middle East and North Africa Region." World Bank Policy Research Working Paper.3837 (2006). Print.

- The Strategic Role of Exports in Trade Expansion and Economic Growth for Romania. Proceedings of the International Management Conference 2014. Faculty of Management, Academy of Economic Studies, Bucharest, Romania. Print.

- Egger, Peter. "An Econometric View on the Estimation of Gravity Models and the Calculation of Trade Potentials." The World Economy 25.2 (2002): 297-312. Print.

- On the Problem of Endogenous Unobserved Effects in the Estimation of Gravity Models: WIFO, 2000. Print.

- Eichengreen, Barry, Yeongseop Rhee, and Hui Tong. The Impact of China on the Exports of Other Asian Countries: National Bureau of Economic Research, 2004. Print.

- Ferrantino, Michael. "Quantifying the Trade and Economic Effects of Non-Tariff Measures." (2006). Print.

- Frankel, Jeffrey, and Andrew Rose. "An Estimate of the Effect of Common Currencies on Trade and Income." Quarterly Journal of Economics (2002): 437-66. Print.

- Galal, Ahmed, and Bernard Hoekman. "Between Hope and Reality: An Overview of Arab Economic Integration." Arab Economic Integration, between hope and reality. Egyptian Center for Economic studies (2003): 1-12. Print.

- Greenaway, David, Aruneema Mahabir, and Chris Milner. "Has China Displaced Other Asian Countries' Exports?" China Economic Review 19.2 (2008): 152-69. Print. 
- Hakimian, Hassan, and Jeffrey B Nugent. Trade Policy and Economic Integration in the Middle East and North Africa: Economic Boundaries in Flux. Vol. 1: Psychology Press, 2005. Print.

- Harrigan, Jane. Food Security in the Middle East and North Africa (Mena) and SubSaharan Africa: A Comparative Analysis: Center for Economic Institutions, Institute of Economic Research, Hitotsubashi University, 2011. Print.

- The Political Economy of Arab Food Sovereignty. Palgrave Macmillan, 2014. Print.

- IFAD, The International Fund for Agricultural Development, and United NationsFood and Agriculture Organization FAO. Improving Food Security in the Arab Countries2009. Print.

- IFPRI, International Food Policy Research Institute. Food Security and Economic Development in the Middle East and North Africa: Current State and Future Perspectives. Washington DC: IFPRI2010. Print.

- Middle East and North Africa Strategy2010. Print.

- ITC, International Trade Center. League of Arab States's Regional Integration: Opportunities for Trade and Development: ITC, Market Analysis and Research, 2012. Print.

- Kavallari, Aikaterini, Sarah Maas, and P Michael Schmitz. "Evidence on Euromediterranean Trade Integration: The Case of German Olive Oil Imports." Journal of International Agricultural Trade and Development 59.1 (2010). Print.

- Kleiman, Ephraim. Geography, Culture and Religion and Middle East Trade Patterns. Hebrew University of Jerusalem, Department of Economics, 1992. Print.

- Lampietti, Julian A, et al. "A Strategic Framework for Improving Food Security in Arab Countries." Food Security 3.1 (2011): 7-22. Print.

- Limam, Imed, and Adil Abdalla. "Inter-Arab Trade and the Potential Success of Afta." (1998). Print.

- Lloyd, Peter J, and Donald MacLaren. "Gains and Losses from Regional Trading Agreements: A Survey*." Economic Record 80.251 (2004): 445-67. Print.

- Malvarosa, Loretta. "The Fish Trade of North African Mediterranean Countries: Intra-Regional Trade and Import-Export with the European Union." FAO Fisheries Circular (FAO) (2002). Print.

- Martínez-Zarzoso, Inmaculada, Nowak-Lehmann D Felicitas, and Nicholas Horsewood. "Are Regional Trading Agreements Beneficial?: Static and Dynamic Panel Gravity Models." The North American Journal of Economics and Finance 20.1 (2009): 46-65. Print.

- Martínez-Zarzoso, Inmaculada, and Felicitas Nowak-Lehmann. "Augmented Gravity Model: An Empirical Application to Mercosur-European Union Trade Flows." Journal of applied economics 6.2 (2003): 291-316. Print.

- Neaime, S. South South Trade, Monetary and Financial Integration and the EuroMediterranean Partnership: An Empirical Investigation2005. Print.

- Pöyhönen, Pentti. "A Tentative Model for the Volume of Trade between Countries." Weltwirtschaftliches Archiv (1963): 93-100. Print.

- Redding, Stephen, and Anthony J Venables. "Economic Geography and International Inequality." Journal of international Economics 62.1 (2004): 53-82. Print. 
- Rojid, Sawkut. "Comesa Trade Potential: A Gravity Approach." Applied Economics Letters 13.14 (2006): 947-51. Print.

- Romagnoli, Alessandro, and Luisa Mengoni. "The Challenge of Economic Integration in the Mena Region: From Gafta and Eu-Mfta to Small Scale Arab Unions." Economic change and restructuring 42.1-2 (2009): 69-83. Print.

- The Economic Development Process in Mena. Routledge, 2013. Print.

- Sarker, Rakhal, and Sampath Jayasinghe. "Regional Trade Agreements and Trade in Agri-Food Products: Evidence for the European Union from Gravity Modeling Using Disaggregated Data." Agricultural Economics 37.1 (2007): 93-104. Print.

- Shepherd, Ben. "The Gravity Model of International Trade: A User Guide." United Nations publication. Bangkok (2013). Print.

- Taleb, W, and H Younes. "Augmented Gravity Model: An Empirical Application to Arab Mediterranean Countries European Union Trade Flows." Bridging the Gap: The Role of Trade and FDI in the Mediterranean, CUEN, Napoli (2008): 239-75. Print.

- Tenreyro, Silvana. "On the Trade Impact of Nominal Exchange Rate Volatility." Journal of Development Economics 82.2 (2007): 485-508. Print.

- Terad, Belkassem. MSc dissertation. ." Arab Bilateral Trade and Its Role in Achieving Economic Integration: A Case Study on the Golf Cooperation Council Countries." Muhammed Khedr University, 2013. Print.

- Tinbergen, Jan. "Shaping the World Economy; Suggestions for an International Economic Policy." (1962). Print.

- Trabelsi, Imen. "Agricultural Trade Face to Non-Tariff Barriers: A Gravity Model for the Euro-Med Area." Journal of Studies in Social Sciences 3.1 (2013). Print.

- Wacziarg, Romain. "Measuring the Dynamic Gains from Trade." The world bank economic review 15.3 (2001): 393-429. Print.

- Westerlund, Joakim, and Fredrik Wilhelmsson. "Estimating the Gravity Model without Gravity Using Panel Data." Applied Economics 43.6 (2011): 641-49. Print.

- Wilson, John S, Catherine L Mann, and Tsunehiro Otsuki. "Assessing the Benefits of Trade Facilitation: A Global Perspective." The World Economy 28.6 (2005): 84171. Print.

- Yihong, Tang, and Wang Weiwei. "An Analysis of Trade Potential between China and Asean within China-Asean Fta." WTO, China and the ASEAN Economies, IV: Economic Integration and Economic Development, University of International Business and Economics, Beijing, China, June (2006): 24-25. Print.

- The Contribution of Trade to Growth of the Arab Countries. Conference on Empirical Investigation in Trade and Investment. March. 2010. Print.

- Zarrouk, Jamel. "The Greater Arab Free Trade Area: Limits and Possibilities." Studies in International Economics (2000): 285-305. Print.

- "A Survey of Barriers to Trade and Investment in Arab Countries." Arab economic integration: Between hope and reality (2003): 48. Print. 
تهدف الدر اسة إلى تقييم أثز جهود التكامل الإقتصادي الإقليمي على التجارة العربية فيما يتعلق بالسلع الزر اعية والغذائية ـ وتشير النتائج التجريبية أن هذه الجهود لا زالت غير فاعلة في دعم التبادل التجاري العربي في السلع موضوع الدر اسة. كما توضح نتائج الدر اسة أن القيم الو اقعية لحجم التبادل العربي في السلع الزر اعية والغذائية أقل بكثثر من القيم التي تتبأ بها النموذج القياسي المستخدم في التقدير (نموذج الإنسيابية). علاوة على ذلك، تبين النتائج أن اتفاقيات التجارة العربية البينية كان لها تأثير منو اضع على مستوى التجارة العربية البينية في السلع الزر اعية و الغذائية. ومن هذه النتائج يمكن استتناج التالى: ( ) هناك امكانية وفرص غير مستغلة لتوسيع نطاق التجارة العربية البينية في السلع الزر اعية و الغذائية ، r) على الرغم من الجهود العربية المستمرة لتخفيض قيم التعريفة الجمركية على السلع الزراعية و الغذائية المتبادلة، ظل مستوى التبادل التجاري العربي أقل من الإمكانيات المتاحة الأمر الذي يشير إلى وجود عو ائق تجارية غير جمركية أخرى تعرقل تدفق السلع الزراعية و الغذائية بين الدول العربية. 